\title{
PENGARUH FAKTOR-FAKTOR MOTIVASI DITINJAU DARI SISI GAYA KEPEMIMPINAN,KOMUNIKASI DAN SEMANGAT BELAJAR SISWA TERHADAP PRESTASI BELAJAR SISWA STUDI KASUS PADA SMA Dr. SOETOMO SURABAYA
}

\author{
*( Nurus Safa'atillah \\ Fakultas Ekonomi \\ Universitas Islam Lamongan
}

\begin{abstract}
ABSTRAK
Penelitian ini bertujuan untuk mengetahui pengaruh gaya kepemimpinan, komunikasi dan semangat belajar terhadap prestasi belajar siswaSMA Dr.SoetomoSurabaya. responden yang terlibat dalam penelitian ini sebanyak 100 siswa. metode yang digunakan adalah sampel populasi. pengumpulan data dilakukan dengan menyebar angket. metode analisis data dilakukan dengan regresi linier berganda menggunakan software spss. hasil uji regresi menunjukkan bahwa variabel gaya kepemimpinan,komunikasi dan semangat belajar berpengaruh positif dan signifikan terhadap prestasi belajar siswa sedangkan variabel yang dominan pengaruhnya terhadap prestasi belajar siswa adalah semangat belajar siswa berdasarkan hasil penelitian tersebut dapat disimpulkan bahwa gaya kepemimpinan,komunikasi dan semangat belajar siswa berpengaruh positif terhadap prestasi belajar siswa.
\end{abstract}

Kata kunci :gaya kepemimpinan), Komunikasi),semangat belajar), prestasi belajar

\section{PENDAHULUAN}

Seorang pendidik adalah orang yang melakukan sesuatu melalui orang lain, dengan membagi dan mengalokasikan tugas-tugas kepada anak didiknya. Keberhasilan seorang guru ditentukan oleh seberapa jauh anak didiknya menjalankan tugas yang telah diberikan degan baik.

Seorang siswa mungkin menjalankan pekerjaan yang dibebankan kepadanya dengan baik, mungkin juga tidak. Namun, bila tugas yang dibebankan kepada dirinya tidak bisa terlaksana dengan baik, maka guru perlu menganalisis apa penyebabnya. Dalam hal ini, kemungkinan-kemungkinan yang dapat terjadi adalah, pertama, siswa memang tidak mempunyai kemampuan untuk menyelesaikan pekerjaan yang ditugaskan. Kedua, siswa tidak mempunyai motivasi untuk belajar dengan baik. Kemungkinan yang ketiga, bisa jadi merupakan kombinasi atau gabungan dari kedua faktor tersebut.

Siswa yang belajar dengan motivasi tinggi merupakan harapan sekolah.Siswa yang tidak memiliki motivasi untuk belajar tidak sama dengan siswa yang belajar dengan motivasi yang tinggi. Siswa yang belajar dengan motivasi tinggi ini pada umunnya beranggapan sekolah hanya untuk mencari ijasah sebagai bekal untuk mencari pekerjaan. Inilah yang disebut dengan motivasi ekstrinsik (As'ad, 1991). Siswa dengan perilaku seperti ini tidak termotivasi untuk belajar semaksimal mungkin dan 
memiliki Quality of Work Life yang mempengaruhi kualitas kehidupannya. Dengan demikian, yang dibutuhkan sekolah adalah siswa yang belajar dengan motivasi yang tinggi yaitu merasa senang mendapat kepuasan dalam proses belajar.

Dengan terciptanya kepuasan belajar pada siswa maka akan diharapkan terjadi peningkatan mutu pelayanan karena bila siswa merasa puas dan senang dalam belajar akan dapat melakukan tugasnya dengan baik dan tulus dalam menjalankan apa yang menjadi kewajibannya. Selain itu, kepuasan belajar akan membawa dampak para turnover, absensi dan potensi siswa akan tergali dengan benar sehingga diharapkan guru bisa membimbing dan menyalurkan bakat dan kemampuan siswa yang akan berguna bagi masa depannya kelak.

Bertolak dari uraian diatas, dalam kesempatan ini penulis bermaksud mengkaji sejauh mana pengaruh faktorfaktor motivasi terhadap prestasi belajar siswa dalam suatu organisasi khususnya organisasi sekolah. Kajian studi ini selanjutnya akan di wujudkan dalam bentuk penelitian tesis (internship) dengan judul

\section{"PENGARUH FAKTOR-FAKTOR MOTIVASI DITINJAU DARI SISI GAYA KEPEMIMPINAN GURU ,KOMUNIKASI DAN SEMANGAT BELAJAR TERHADAP PRESTASI BELAJAR SISWA STUDI KASUS PADA SMA DR. SOETOMO SURABAYA".}

\section{Gaya Kepemimpinan}

Setiap pemimpin bisa mempunyai gaya kepemimpinan yang berbeda antara yang satu dengan yang lain, dan tidak mesti suatu gaya kepemimpinan lebih baik atau lebih jelek dari pada gaya kepemimpinan yang ada dengan menggunakan dasar tertentu.
Berikut gaya kepemimpinan menurut Jeff Harris :

a. The Autocratic leader

Seorang pemimpin yang otokratik menganggap bahwa semua kewajiban untuk mengambil keputusan, untuk menjalankan tindakan, dan untuk mengarahkan, memberi motivasi dan pengawasan bawahan terpusat ditangannya.

b. The participative leader

Apabila seorang pemimpin menggunakan gaya partisipasi ia menjalankan kepemimpinannya dengan konsultasi. Ia tidak mendelegasikan wewenangnya untuk membuat keputusan akhir dan untuk memberikan pengarahan tertentu kepada bawahan mengenai keputusan yang akan diambil.

c. The free rein leader

Di sini pimpinan menyerahkan tanggung jawab atas pelaksanaan pekerjaan tersebut kepada para bawahan dalam artian pimpinan menginginkan agar para bawahan bisa mengendalikan diri mereka sendiri di dalam menyelesaikan pekerjaan tersebut.

\section{Teori Kepemimpinan dan Pendekatan Kepemimpinan}

Sebelum mencoba untuk menganalisa kedudukan kepemimpinan suatu organisasi, perlu menelusuri perkembangan teori kepemimpinan terlebih dahulu. Beberapa teori tersebut diantaranya (Sukanto Reksohadiprojo, dan T. Hani Handoko, 1996)

1. Teori kepemimpinan

a. Teori sifat kepemimpinan

Teori ini mengatakan bahwa seseorang itu dilahirkan membawa atau tidak membawa sifat-sifat yang diperlukan bagi pimpinan atau tidak membawa sifat-sifat yang diperlukan bagi pimpinan atau dengan individu yang lahir telah membawa ciri-ciri tertentu yang memungkinkan dia menjadi seorang pemimpin.

b. Teori Path-Goal 
Teori ini merupakan pengembangan yang wajar sebab kepemimpinan erat hubungannya dengan motivasi di satu pihak dan kekuasaan di pihak lain. Teori Path - Goal ini menganalisa pengaruh kepemimpinan terhadap motivasi bawahan, kepuasan dan pelaksanaan kerja.

c. Teori sifat

Teori ini merupakan analisa ilmiah tentang kepemimpinan, dimiliki dengan memusatkan perhatian pada pemimpin itu sendiri. Ada beberapa faktor yang bisa diteliti dari kepemimpinan yaitu: kecerdasan, perasaan humor, kejujuran, simpati, dan percaya diri.

d. Teori kelompok

Teori beranggapan bahwa kelompok bisa mencapai tujuannya dengan melalui pertukaran positif antara pimpinan dan bawahan.

2. Pendekatan kepemimpinan

Berbagai studi tentang kepemimpinan mengelompokkan pendekatan kepemimpinan menjadi tiga pendekatan yaitu :

a. Pendekatan atas traits

Yaitu pendekatan berdasarkan sifat, perangai atau kualitas yang diperlukan seseorang untuk menjadi pimpinan.

b. Pendekatan behavior (perilaku)

Yaitu pendekatan yang mempelajari perilaku yang diperlukan untuk menjadi pemimpin yang efektif.

c. Pendekatan contingency

Yaitu pendekatan berdasarkan atas faktor-faktor situasional, untuk menentukan gaya kepemimpinan efektif.

\section{Komunikasi}

Ada beberapa pendapat tentang komunikasi, antara lain dikemukakan oleh American Training Director, Newman, Koontz dan O’ Donnell yang diterjemahkan oleh Basu Swastha. American Training Director memberikan definisi komunikasi : .... "sebagai pertukaran pikiran atau informasi agar supaya terdapat saling pengertian serta hubungan antar manusia-manusia secara serasi". (American Training Director, $1994 ; 31)$.

Sedangkan Koontz dan O'Donnell ; mengartikan komunikasi : ... "sebagai suatu pemindahan informasi antara orang yang satu dengan yang lainnya “ (Basu Swastha, 1995 ; 115). Dari definisi-definisi tentang komunikasi tersebut dapat diambil kesimpulan bahwa :

1. Didalam Komunikasi terdapat hubungan antara orang dengan orang, orang dengan lembaga dan sebaliknya.

2. Hubungan yang timbul didalam komunikasi itu digunakan untuk menyalurkan gagasan, pendapat atau informasi.

3. Komunikasi berguna untuk menciptakan hubungan yang serasi dan menciptkan saling pengertian.

4. Untuk mengadakan komunikasi, dapat digunakan kata-kata, surat, kode atau simbol.

\section{Proses Komunikasi}

Dalam proses komunikasi terdapat tahap-tahap dimana suatu gagasan atau pengertian dikirimkan dari sumbernya, yang disebut sebagai komunikator atau pengirim, sampai gagasan atau pengertian tersebut dijalankan oleh yang menjadi sasaran komunikasi, yang disebut komunikan atau penerima. Memahami proses komunikasi, beserta hambatan yang mungkin terjadi, maka akan dicapai komunikasi yang efektif.

Proses komunikasi itu terjadi dimulai ketika pengirim menyadari adanya suatu kebutuhan atau alasan untuk menyampaikan suatu pesan kepada orang lain, pengirim mempunyai informasi atau bahan-bahan untuk kerja sama yang mungkin sangat penting untuk penerima. Pada saat pengirim merencanakan penyampaian pesannya ia 
mempertimbangkan pengetahuan dan kebutuhan penerima terhadap masalah yang akan dikomunikasikan serta latar belakang informasi lainnya.

\section{Teknik Pelaksanaan Komunikasi Secara Organisasional}

Latar belakang yang mendorong seorang pemimpin untuk mengadakan komunikasi ditinkau dari teknik pelaksanaan dalam rangka kegiatan secara organisasi. Seorang pemimpin akan disorot cara-cara mengadakan hubungan kerja

yang berdaya guna dengan seluruh unsur yang terlihat dalam suatu kesatuan kerja. Dalam hal ini akan dibahas beberapa teknik komunikasi sebagai alat penilaian kinerja dan juga kendala dalam teknik komunikasi.

Meskipun setiap individu mempunyai kemampuan untuk berkomunikasi tetapi tanpa adanya pengenalan dan kemampuan melihat tipe manusia lain sebagai lawan bicaranya, teknik komunikasi sering kali gagal berfungsi sebagai mediator penyampaian pesan. Ada beberapa hal yang perlu diperhatikan pada teknik komunikasi seperti yang dikemukakan oleh Dr. Kartini Kartono (1994 : 90) :
a. Manfaat Komunikasi
b. Arus Komunikasi
c. Kebijaksanaan Komunikasi
d. Tipe dan Persyaratan Komunikasi
e. Bentuk-bentuk komunikasi

\section{Pengertian dan Pentingnya Mengenai Komunikasi Organisasional}

Setelah telah diuraikan sebelumnya komunikasi merupakan penyampaian pesan dari komunikator (pengirim pesan) kepada komunikan (penerima pesan) dengan menggunakan lambang-lambang yang berarti dan mengerti kedua belah pihak yang melakukan kegiatan komunikasi. Komunikasi menyebabkan adanya pembentukan pengertian kelompok, adanya pembentukan norma kelompok, adanya aktivitas kelompok untuk mencapai tujuan bersama serta adanya dinamika suatu kelompok. Pentingnya komunikasi dalam suatu organisasi atau lembaga karena banyak kita lihat adanya dinamika kehidupan suatu kelompok dalam organisasi, sehingga timbul pula pertentangan karena salah pengertian atau kurang informasi yang diperoleh suatu anggota organisasi.

Ada beberapa keuntungan dengan dilaksanakannya komunikasi yang baik oleh organisasi, yaitu :

1. Kelancaran tugas-tugas lebih terjamin

2. Biaya-biaya dapat ditekan

3. Dapat meningkatkan partisipasi

4. Pengawasan dapat dilaksanakan dengan baik (Pandji Anoraga, 1997 ; 101).

sekolah tentu akan mendapat hambatanhambatan. Hambatan-hambatan dalam komunikasi antara lain :
a. Hambatan Teknis
b. Hambatan Semantik (pemaknaan)
c. Hambatan Manusiawi
d. Hambatan Psikologis
e. Hambatan Kurangnya Motivasi
f. Hambatan karena banyaknya perantara
g. Hambatan Kurangnya Partisipasi (Alex S. Nitisemito, 1996 ; 150)

\section{Pengertian Semangat Belajar}

Menurut Alex S. Nitisemito : "Semangat belajar adalah melakukan pekerjaan secara lebih giat sehingga dengan demikian pekerjaan akan dapat diharapkan lebih cepat dan lebih baik" (Alex S. Nitisemito, 1996 ; 96).

Menurut Malayu S. P. Hasibuan : "Semangat kerja adalah keinginan dan kesungguhan seseorang mengerjakan pekerjaannya dengan baik serta berdisiplin untuk mencapai prestasi kerja yang maksimal" (Malayu S.P. Hasibuan, 1995 ; 105).

Dari kutipan diatas disimpulkan bahwa semangat kerja adalah sesuatu hasil yang terlihat pada mental seseorang dalam melakukan pekerjaan secara lebih cepat 
dan lebih baik untuk mencapai prestasi kerja yang maksimal dalam suatu organisasi.

Semangat kerja buruh/pekerja merupakan hal yang sangat penting antara lain dengan diberikannya motivasi oleh pimpinan perusahaan, semangat kerja yang rendah dapat menghambat tercapainya tujuan organisasi.

Seorang guru harus dapat mengetahui indikator-indikator atau tanda tanda menurunnya semangat kerja para siswa. Dalam mengukur semangat kerja siswa dapat digunakan indikator-indikator menurut Alex S. Nitisemito yang terdiri dari :

1. Tingkat pemahaman siswa

Merupakan perbandingan antara output dengan input, dimana output adalah hasil pekerjaan siswa yang menggambarkan tingkat kemampuan dan prestasi siswa.

2. Tingkat Absensi siswa

Merupakan ketidakhadiran siswa pada hari sekolah karena sakit, ijin, mangkir dan skorsing.

3. Tingkat Perputaran siswa

Merupakan perbandingan antara masuk dan keluarnya siswa pada suatu Sekolah pada periode tertentu.

4. Tingkat Kesalahan

Merupakan naiknya tingkat kesalahan tersebut menunjukkan bahwa perhatian dalam pekerjaan berkurang terjadinya kecerobohan dalam pekerjaan.

5. Kegelisahan/Keluhan

Kegelisahan yang timbul akan dapat terwujud dalam bentuk Ketidaksenangan belajar, keluh kesah, ketidaktenangan siswa dalam melaksanakan tugas.

6. Tuntutan

Merupakan perwujudan dari ketidak puasan siswa, dimana tiap tahap tertentu akan menimbulkan keberanian untuk mengajukan tuntutan.
7. Pemogokan belajar

Pemogokan merupakan perwujudan dari ketidakpuasan, kegelisahan dan lain sebagainya.

\section{Peranan Semangat belajar siswa}

Apabila sekolah mampu meningkatkan semangat belajar siswa maka akan menimbulkan :

1. Pekerjaan dan tugas akan cepat diselesaikan

Semangat belajar yang dimiliki oleh personel dalam belajar menumbuhkan gairah dan motivasi yang tinggi terhadap penyelesaian pekerjaan.

2. Kesalahan akan dapat dikurangi

Semangat belajar yang tinggi cenderung menimbulkan kehati-hatian dalam melaksanakan pekerjaan dan tugastugas.

3. Absensi akan dapat diperkecil

Indikator yang jelas dari semangat belajar adalah tentang absensi. Absensi yang rendah menunjukkan semangat belajar siswa yang tinggi. Sebaliknya absensi yang tinggi menunjukkan gairah belajar siswa menurun.

4. Perpindahan sekolah siswa dapat diperkecil seminimal mungkin Siswa yang bersemangat cenderung menunjukkan gejala untuk keluar dari perusahaan sangat kecil.

Dari definisi yang dikemukakan diatas dapat disimpulkan bahwa peranan semangat belajar cukup besar dalam meningkatkan efektivitas dalam proses pembelajaran.

\section{Prestasi Belajar \\ Pengertian Prestasi Belajar}

Organisasi sekolah sebagai suatu sistem, berarti organisasi perusahaan tidak dapat lepas dari lingkungannya baik yang bersifat internal maupun eksternal. Lingkungan yang melingkupi dan mempengaruhi jalannya organisasi, sifatnya selalu berubah dan berkembang sesuai dengan tuntutan lingkungan bisnis 
yang di masukinya. Memenuhi tuntutan lingkungan berarti dapat memanfaatkan kesempatan dan mengatasi tantangan/ancaman dari lingkungan yang komplek. Oleh karena itu sebagai konsekuensinya organisasi sekolah harus melakukan berbagai kegiatan dalam rangka menghadapi atau memenuhi kegiatan tersebut.

Salah satu tantangan yang harus dihadapi adalah pemenuhan kebutuhan-kebutuhan siswa yang didalamnya termasuk kebutuhan akan berprestasi. Menurut Suprihanto (1988:70), yang dimaksud dengan prestasi kerja adalah hasil kerja seseorang selama periode tertentu dibandingkan dengan berbagai kemungkinan misalnya target, standar ataupun kriteria yang telah ditentukan terlebih dahulu dan telah disepakati bersama.

Pelaksanaan belajar dalam arti prestasi belajar tidak hanya menilai hasil fisik yang telah dihasilkan oleh seorang murid. Pelaksanaan belajar disini dalam artian secara keselurahan sehingga dalam penilaian prestasi belajar ditunjukkan berbagai bidang seperti kemampuan kecerdasan siswa, kerajinan, disiplin, hubungan dengan sesama teman dan sebagainya.

Pembinaan dan pengembangan terhadap siswa adalah salah satu kegiatan dalam rangka penyesuaian diri dengan perubahan dan perkembangan lingkungan yang terjadi. Dalam melaksanakan pembinaan dan pengembangan para siswa maka perlu dilakukan penilaian atas pekerjaan yang telah dilaksanakan oleh siswa tersebut.

Selanjutnya Suprihanto (1936: 78) menyatakan juga bahwa penilaian prestasi belajar adalah suatu sistem yang digunakan untuk menilai dan mengetahui sejauh mana seorang siswa telah melaksanakan pekerjaannya masing-masing secara keseluruhan.

\section{Manfaat dan Tujuan Penilaian Prestasi Kerja}

Penilaian prestasi kerja atau penilaian pelaksanaan pekerjaan tidak dapat dipisahkan dengan kebijaksanaan guru dalam pengelolaan kelas. Demikian juga kebijaksanaan guru dalam pengelolaan kelas tidak dapat dipisahkan dengan kebijaksanaan yang diberlakukan di sekolah.

Khusus dalam masalah penilaian pelaksanaan pekerjaan para siswa, pada dasarnya berlaku bagi seluruh siswa tanpa memandang kedudukan, kecantikan, kekayaan dari semua siswa. Dengan pelaksanaan penilaian pekerjaan yang seperti ini akan menumbuhkan suasana belajar yang sehat, bersemangat, saling menghargai dan rasa memiliki sekolah sebagai satu kesatuan. Untuk itu semua tentunya dibutuhkan sistem penilaian pelaksanaan pekerjaan yang jelas dan obyektif yang dapat digunakan sebagai pedoman dalam menilai siswa secara adil.

Adapun yang menjadi manfaat serta tujuan dari penilaian prestasi belajar ini adalah sebagai berikut (Prawirosentono, 1999: 99):

1. Mengetahui keadaan keterampilan dan kemampuan setiap siswa secara rutin.

2. Digunakan sebagai dasar perencanaan seorang guru khususnya penyempurnaan kondisi peningkatan mutu dan hasil belajar siswa.

3. Dapat digunakan sebagai dasar pengembangan dan pendayagunaan siswa secara optimal.

4. Mendorong terciptanya hubungan timbal balik yang sehat antara guru dan murid.

5. Mengetahui kondisi sekolah secara keselurahan dari bidang personalia, khususnya prestasi siswa dalam belajar.

6. Secara pribadi bagi siswa dapat 


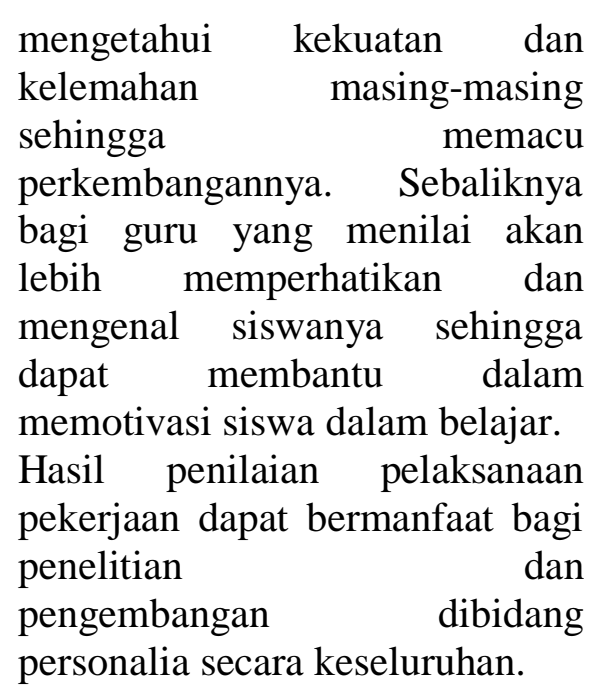

\section{Pengukuran Prestasi Belajar}

Dalam melakukan penilaian terhadap pelaksanaan pekerjaan ,atau prestasi belajar seorang guru harus memiliki pedoman atau indikator penilaian, yaitu hal-hal yang pada dasarnya merupakan sifat-sifat atau ciri-ciri yang dapat menunjukkan bahwa pelaksanaan suatu pekerjaan tertentu dapat berjalan dengan lancar dan baik.

Menurut Suprihanto (1986: 81), pengukuran prestasi belajar siswa dapat dilakukan dengan melihat kualitas kerja, kuantitas pekerjaan, pemahaman dan pengenalan pekerjaan, tanggung jawab, ketaatan, kejujuran, serta kerja sama. Dalam penelitian ini tingkat prestasi seorang siswa dapat dilihat dari total skor jawaban kuesioner yang diberikan kepada siswa SMA Dr.Soetomo.

\section{METODE PENELITIAN}

\section{Jenis dan Rancangan Penelitian}

Penelitian yang digunakan adalah dengan pendekatan kuantitatif. Dimana penelitian kuantitatif menekankan pada pengujian teori - teori melalui pengukuran variabel penelitian dengan angka dan melakukan analisis dengan prosedur statistik. Dalam penelitian ini peneliti menggunakan tiga macam variable yaitu Gaya Kepemimpinan (X1), Komunikasi (X2), Semangat Belajar(X3) dan loyalitas pelanggan sebagai variable (Y)

\section{Kesimpulan}

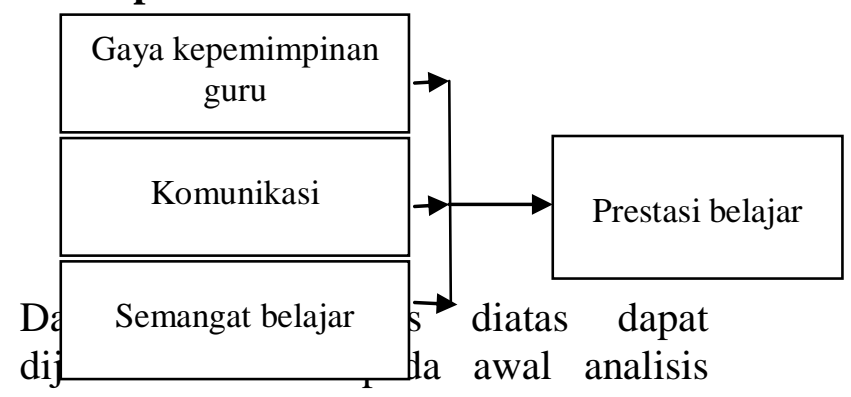

diasumsi berbagai macam variable yang dimungkinkan mempengaruhi prestasi belajar siswa SMA Dr.Soetomo Surabaya.Setelah ditentukan selanjutnya variable tersebut dianalisis dengan menggunakan analisis factor yang sebelumnya dilakukan pengujian instrument.Dari hasil analisis factor akan diketahui variable yang berhubungan dan berpengaruh besar terhadap meningkatnya prestasi belajar siswa SMA Dr. Soetomo Surabaya.

Untuk menganalisis data penelitian ini digunakan deskriptif dan uji regresi. Deskriptif digunakan untuk memberikan gambaran tentang motivasi dan prestasi kerja yang akan disajikan dalam bentuk tabel. Regresi digunakan untuk mengetahui atau menguji apakah ada pengaruh yang positif atau tidak antara motivasi dengan prestasi kerja. Selanjutnya, diterima atau tidak diterimanya hipotesis yang diajukan dilakukan dengan uji $\mathrm{F}$ (F-test) dan uji t (T-test).

\section{a. Pengujian hipotesis I}

Pembuktian kebenaran hipotesis I, menggunakan uji $\mathrm{F}$ (F-test) yaitu untuk enguji keberartian koefisiensi secara simultan (keseluruhan) dengan formulasi operasional hipotesis sebagai berikut:

Ho:bl=b2 = b3 = 0

Ha: $\mathrm{bl} \neq \mathrm{b} 2 \neq \mathrm{b} 3 \neq 0$

Pengujian uji $\mathrm{F}$ adalah dengan membandingkan $\mathrm{F}$ hitung dengan $\mathrm{F}$ tabel pada $\alpha=0,05$. Kesimpulan diperoleh melalui hasil perhitungan sebagai 
berikut:

a. F hitung > F tabel, maka Ho
ditolak dan Ha diterima, artinya
variabel independennya secara
simultan mempengaruhi variabel
dependennya.
b. $\mathrm{F}$ hitung $\leq \mathrm{F}$ tabel, maka Ho
diterima dan Ha ditolak, artinya
variabel independennya secara
simultan tidak mempengaruhi
variabel dependennya.

Selanjutnya untuk melihat kemampuan variabel independen dalam menerangkan variabel dependen dapat diketahui dari besarnya koefisien determinasi berganda $\left(\mathrm{R}^{2}\right)$. Dengan kata lain, nilai koefisien $\mathrm{R}^{2}$ digunakan untuk mengukur besarnya sumbangan variabel independen terhadap variasi variabel dependennya. Jika $\mathrm{R}^{2}$ diperoleh dari hasil perhitungan semakin besar atau mendekati 1 maka dapat dikatakan bahwa sumbangan dari variabel independen terhadap variasi variabel dependen semakin besar. Itu berarti model yang digunakan semakin kuat untuk menerangkan variabel dependennya. Sebaliknya jika $\left(\mathrm{R}^{2}\right)$ semakin kecil atau mendekati 0 maka dapat dikatakan bahwa sumbangan dari variabel independen terhadap variasi variabel dependen semakin kecil. Hal ini berarti model yang digunakan semakin lemah untuk menerangkan variasi variabel dependennya. Secara umum dapat dikatakan bahwa besarnya koefisien determinasi berganda $\left(\mathrm{R}^{2}\right)$ berada diantara 0 dan 1 atau $0 \leq\left(\mathrm{R}^{2}\right) \leq 1$.

\section{b. Pengujian hipotesis II}

Untuk membuktikan hipotesis II, maka digunakan uji $t$ (T-test) yaitu untuk menguji keberartian koefisien regresi parsial dengan menggunakan formulasi hipotesis sebagai berikut:

Ho $: b_{1}=0$

Ha: $b i \neq 0$

Pengujian dilakukan melalui uji t (T-test) dengan cara membandingkan $t$ hitung dengan $\mathrm{t}$ tabel pada $\alpha=0,05$. Apabila hasil pengujian menunjukkan:

a. $t$ hitung $>\mathrm{t}$ tabel maka Ho ditolak dan Ha diterima. Artinya, variabel independen mempengaruhi secara signifikan terhadap variabel dependen.

b. $\mathrm{t}$ hitung $\leq \mathrm{t}$ tabel maka Ho diterima dan Ha ditolak. Artinya, variabel independen mempengaruhi variabel dependennya tetapi tidak signifikan.

Semakin besar $\mathrm{t}$ hitung suatu variabel independen menunjukkan semakin dominan variabel independen tersebut terhadap variabel dependennya.

Dapat disimpulkan bahwa faktor yang paling berpengaruh terhadap prestasi belajar siswa adalah faktor internal yaitu semangat belajar siswa dan ditunjang dengan gaya mengajar dan komunikasi yang baik antara guru denganh siswa.

\section{Saran}

Dalam rangka meningkatkan prestasi belajar siswa seharusnya tenaga pendidik mampu membangkitkan semangat belajar siswa dengan ditunjang bantuan dari para orang tua peserta didik karena semangat belajar dari hasil penelitian merupakan faktor yang paling dominan dalam menentukan prestasi belajar siswa.Selain itu harus ditunjang pula dengan gaya mengajar dan komunikasi yang baik antara pendidik dan pserta didik.

\section{DAFTAR PUSTAKA}

Anwari, 2000. Motivasi: Perangkat Analisis Untuk Para Manajer. Usahawan, No. 12, Th. XXIX, Desember. Hal. 34-40

Arep, Ishak dan Hendri Tanjung. 2003.

Manajemen Dan Motivasi 2003. Jakarta: Grasindo As'ad, Moh., 1991. Psikologi Industri, Yogyakarta: Liberty.

Baswartono, 1997. Mengkaji Ulang Hubungan Antara Motivasi, 
Manajemen dan Produktivitas. Usahawan, No. 09, Thn. XXVI, September. Hal. 31-32

Gibson, James L., Ivancevich, John M., and Donelly JR, James H., 1997. Organisasi: Perilaku, Struktur, Proses. (Alih bahasa: Nunuk Adiarni), Edisi Kedelapan, Jakarta : Binarupa Aksara.

Handoko, T. Hani, 1986. Manajemen, Edisi Kedua, Yogyakarta: BPFE

Handoko, T. Hani, 1988. Manajemen Personalia dan Sumber Daya Manusia,Edisi Kedua. Yogyakarta: -BPFE

Hasibuan, Malayu S.P., 2002. Manajemen: Dasar Pengertian dan Masalah, Edisi Revisi. Jakarta: PT. Gunung Agung,.

Irianto, Jusuf, 1994. Upaya Meningkatkan Semangat Kerja: Suatu Tinjauan Teoritik Aliran Hubungan Kemanusiaan (Rubrik: Perkembangan Teori). Usahawan, No. 04, Thn. XXIII, April. Hal. 2-5 Mangkunegara, A.A. Anwar Prabu, 2000. Manajemen Sumber Daya Manusia Perusahaan. Bandung: Rosda.

Mangkuprawira, Sjafri. 2002. Manajemen Sumber Daya Manusia Strategik. Jakarta: Ghalia Indonesia

Muchlas, Makmuri, 1999. Perilaku Organisasi. Cetakan ke 1. Yogyakarta: Program Pendidikan Pascasarjana Magister Manajemen Rumah Sakit Universitas Gadjah Mada Yogyakarta

Reksohadiprodjo, Sukanto, dan Handoko, T. Hani, 1986. Organisasi Perusahaan: Teori, Struktur dan Perilaku, edisi kedua, Yogjakarta: BPFE.

Sigit, Suhardi. 2002. Pengantar Metodologi Penelitian SosialBisnis-Manajemen. Edisi 2.

Sinaga, Ramli. 1991, Motivasi Sumber Daya Manusia

Untuk
Meningkatkan Produktivitas.

Usahawan, No. 11, Thn. XX, Nopeinber. Hal. 29-33

Simamora, Henri. 1997. Manajemen

Sumber Daya Manusia. Edisi Ke

2, Yogyakarta: BP-STIE YKPN

Sulistiyani, Ambar Teguh dan Rosidah. 2003. Manajemen Sumber Daya

Manusia. Yogyakarta: Graha llmu

Smvarto, FX., $1999 . \quad$ Perilaku

Keorganisasian: Buku Panduan

Mahasiswa. Yogyakarta:

Universitas Atmajaya.

Syatarudin Alwi, 2001. Manajemen

Sumber Daya Manusia:

Strategi; keunggulan Kompetitif,.

Edisi Pertama. Yogyakarta: BPFE

Umar, Husein. 2001 Riset Sumber Daya Manusia Dalam Organisasi Jakarta: Gramedia Pustaka Utama Wahyusumidjo, 1984. Kepemimpinan dan Motivasi, Jakarta: Ghalia Indonesia. 